\title{
Anticholinergic drugs and open-field behavior in chickens
}

\author{
DANIEL D. MORIARTY, JR. and KIM A. ROBERTS \\ University of San Diego, San Diego, California \\ JOHN L. ALLEN \\ Point Loma College, San Diego, California \\ and \\ CHARLES W. HENNIG \\ Salem College, Salem, West Virginia
}

\begin{abstract}
The effects of scopolamine and atropine on the open-field behavior of Production Red and White Leghorn chickens were examined in order to evaluate the suggestion that the influence of these anticholinergic drugs on tonic immobility was mediated by their impact on emotionality. Significant strain differences in vocalization latency, number of vocalizations, and activity latency were observed. Both of the anticholinergic drugs reduced the chickens' vocalization and activity latencies, but they increased the number of vocalizations and activity levels. Intercorrelations among the various behavioral measures are presented and discussed. The effects of the two independent variables (genetic strain and anticholinergic drugs) on open-field behavior appear consistent with the interpretation that both of them influence the emotionality of subjects.
\end{abstract}

The open-field test has long been used as a measure of general emotionality in many species (see Archer, 1973; Walsh \& Cummins, 1976, for review), although the usefulness of a single emotionality construct has sometimes been questioned (e.g., Archer, 1973). Gallup and Suarez (1980) proposed that researchers view open-field behavior in chickens as a compromise between the tendencies to reinstate social contact and avoid predation. Suarez and Gallup (1980, 1981a, 1982) suggested similar explanations for open-field behavior in other species such as ducks, rats, mice, and guinea pigs.

Suarez and Gallup (1981b, 1982) also noted that several variables that affected open-field behavior were known to influence tonic immobility (TI), a form of motor inhibition. TI, which appears to be an innate behavior displayed by many animals in response to some form of restraint, is thought to be the final defense in a series of antipredator reactions (Ratner, 1967; Gallup, 1977). TI also seems to be strongly influenced by manipulations designed to affect fear (Gallup, 1977). The neurochemistry of TI has been of special interest to researchers in recent years (e.g., Wallnau \& Gallup, 1977; Wallnau, Bordash, \& Corso, 1981a, 1981b; Hennig, Fazio, Hughes, Castaldi, \& Spencer, 1984; Hennig, Steinhoff, \& Booth, 1986). Studies of cholinergic influences on TI have often

Portions of this paper were presented at the annual meeting of the Western Psychological Association at Long Beach, California, in April 1987. This research was supported in part by a Faculty Research Grant from the University of San Diego to the first author. Reprint requests should be sent to Daniel D. Moriarty, Jr., Department of Psychology, University of San Diego, Alcala Park, San Diego, CA 92110. yielded inconclusive and contradictory results (Thompson, Piroch, Fallen, \& Hatton, 1974; Maser, Gallup, \& Hicks, 1975; Hicks, 1976; Woodruff, Hatton, Frankl, \& Meyer, 1976; Ksir, 1978, 1979; Thompson, 1979; Hughes, 1982). More recent experiments (Hennig, McIntyre, Moriarty, Picerno, \& Allen, in press) have demonstrated that the effects of anticholinergic drugs such as scopolamine and atropine on tonic immobility in chickens can be influenced by the age, strain, genetic population, and pretest handling experience of the subjects, thereby resolving some of the discrepant results in the effects of these drugs on TI. All of these variables may influence the emotionality of the subjects tested for immobility. Hennig et al. (in press) suggested that variations in levels of fear or emotionality might be the mechanism through which anticholinergic drugs influence TI, since these drugs are sometimes thought to reduce fear (Daly, 1968; Carlton, 1969; Plotnik, Mollenauer, \& Snyder, 1974).

The present study attempted to evaluate this interpretation by assessing the effects of the anticholinergic drugs scopolamine and atropine on open-field behavior, since this behavior is often used as an index of emotionality (Archer, 1973) and because similar variables seem to influence both TI and open-field behavior (Suarez \& Gallup, 1981b, 1982). Two different strains of chickens were used as subjects, because TI studies have provided strong evidence suggesting strain differences in emotionality (Gallup, Ledbetter, \& Maser, 1976; Nash, 1978; Hennig et al., in press). The present study also attempted to look for such strain differences in open-field behavior. 


\section{METHOD}

\section{Subjects}

The subjects were 30 Production Red and 30 White Leghorn chicks (Gallus gallus) obtained at one day posthatch from McWilliams Hatchery (Bloomington, CA). They were housed in commercial brooders under a 14-h light/10-h dark cycle of artificial lighting. Food (Purina Chick Starter) and water were always available in the brooders. Because previous findings have related the effects of anticholinergic drugs to age for different strains of chickens (Hennig et al., in press), the Production Reds were tested at 25 days of age, whereas the White Leghorns were tested at 18 days.

\section{Apparatus and Drugs}

A $91.4 \mathrm{~cm}$ square open-field box with $60.9 \mathrm{~cm}$-high sides was used for testing. It was constructed of particle board and painted white. Its floor was marked off into 49 equal-sized squares. The tests were videotaped with a camera suspended $3 \mathrm{~m}$ above the center of the apparatus. The drugs employed were scopolamine hydrochloride (Sigma), at $2 \mathrm{mg} / \mathrm{kg}$ of body weight, and atropine sulfate (Sigma), at $20 \mathrm{mg} / \mathrm{kg}$ body weight. These doses were chosen because they were the same as those used by Hennig et al. (in press).

\section{Procedure}

The chicks were randomly assigned to groups so that ten from each strain were given either a $.1 \mathrm{ml} / 100 \mathrm{~g}$ body weight intraperitoneal injection of distilled water, $2 \mathrm{mg} / \mathrm{kg}$ of scopolamine, or $20 \mathrm{mg} / \mathrm{kg}$ of atropine. Each chick was removed from the brooder, weighed, and given the appropriate injection. Then it was placed in a cardboard box and carried to the testing room. Ten minutes after the injection, the bird was placed in the center square of the open-field apparatus and its behavior was recorded by camera for the next $15 \mathrm{~min}$. Latency of vocalization, number of vocalizations, latency of activity (time required for the bird to leave the center square), and activity level (number of squares entered) were determined by examination of the videotapes.

\section{Statistics}

The data on the four dependent variables were analyzed with separate $2 \times 3$ factorial analyses of variance involving the two strains of chickens (Production Reds or White Leghorns) and the three drug conditions (water, scopolamine, or atropine). Subsequent Newman-Kuels comparisons were used to determine the significance of any differences among the three drug groups. Intercorrelations were also generated among the four variables.

\section{RESULTS}

The mean latencies of vocalization for all six test groups are shown in the upper part of Table 1. The mean latencies for Red and White chicks were $114.2 \mathrm{sec}$ and $340.0 \mathrm{sec}$ respectively; this main effect of strain was significant $[F(1,54)=16.58, p<.001]$. The mean latency

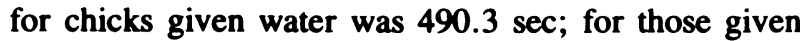
scopolamine and atropine, the mean latencies were $128.3 \mathrm{sec}$ and $62.8 \mathrm{sec}$, respectively. This main effect of drug condition was significant $[F(2,54)=22.98$, $p<.001]$. The Newman-Kuels comparisons revealed that both anticholinergic groups differed significantly from the control group $(p<.01)$, but the mean latency of vocalization for the scopolamine group did not differ from that of the atropine group. A significant strain $x$ drug interaction was also observed $[F(2,54)=9.59$, $p<.001]$. As shown in Table 1, the vocalization latencies of the White chicks were longer than those of the Red chicks, except for when atropine was given.

The mean numbers of vocalizations are also shown in Table 1. As can be seen, the mean number of vocalizations produced by the Production Reds was 120.5; that for the White Leghorns was 27.2. This main effect of strain was significant $[F(1,54)=11.95, p<.001]$. The chicks that were given water produced an overall mean of 38.9 vocalizations. The means for those given atropine and scopolamine were 69.6 and 112.9 , respectively. This main effect of drugs approached, but did not reach, traditional significance levels $[F(2,54)=2.53, p<.10]$. Neither the strain $X$ drug interaction nor the NewmanKuels comparisons were significant.

The mean latencies of activity for the test groups can be seen in the middle part of Table 1 . The overall mean latency for the White chicks was $656.4 \mathrm{sec}$, while the mean for the Red chicks was $396.5 \mathrm{sec}$; this main effect of strain was significant $[F(1,54)=11.65, p<.001]$. The mean latencies for those given water, scopolamine, and atropine were $738.8 \mathrm{sec}, 450.3 \mathrm{sec}$, and $390.4 \mathrm{sec}$ respectively, and the main effect of drugs was significant $[F(2,54)=7.98, p<.001]$. The Newman-Kuels comparisons revealed that both anticholinergic groups differed significantly from the control group $(p<.01)$, but did not differ from each other. The strain $x$ drug interaction was not significant.

The mean activity levels for the various groups are shown in the bottom of Table 1 . The overall mean activity level for the Red chicks was 60.7 squares entered, but it did not differ significantly from that of the White chicks, which was 71.0. The mean activity levels of birds given water, scopolamine, and atropine were 5.3, 80.7,

Table 1

Mean Latencies of Vocalization (in sec), Mean Numbers of Vocalizations, Mean Latencies of Activity (in sec), and Mean Activity Levels in Chickens as a Function of Strain and Anticholinergic Drugs

\begin{tabular}{|c|c|c|c|c|c|c|c|c|}
\hline \multirow[b]{2}{*}{ Drug Group } & \multicolumn{2}{|c|}{$\begin{array}{c}\text { Latencies of } \\
\text { Vocalization } \\
\text { (in sec) }\end{array}$} & \multicolumn{2}{|c|}{$\begin{array}{c}\text { Number of } \\
\text { Vocalizations }\end{array}$} & \multicolumn{2}{|c|}{$\begin{array}{l}\text { Latencies of } \\
\text { Activity } \\
\text { (in sec) }\end{array}$} & \multicolumn{2}{|c|}{ Activity Levels } \\
\hline & PR & WL & PR & WL & PR & WL & PR & WL \\
\hline Water (control) & 221.6 & 758.9 & 76.7 & 1.2 & 631.4 & 846.1 & 9.2 & 1.3 \\
\hline Scopolamine $(2 \mathrm{mg} / \mathrm{kg})$ & 30.6 & 226.0 & 165.7 & 60.1 & 260.8 & 639.8 & 93.8 & 67.6 \\
\hline Atropine $(20 \mathrm{mg} / \mathrm{kg})$ & 90.4 & 35.2 & 119.0 & 20.2 & 297.4 & 483.4 & 72.2 & 144.2 \\
\hline
\end{tabular}

Note-PR $=$ Production Reds; WL $=$ White Leghorns; $n=10$ of each strain per drug group. 
Table 2

Intercorrelations Among Open-Field Behaviors in the Chicken

\begin{tabular}{cccc}
\hline & $\mathrm{V}$ & $\mathrm{AL}$ & $\mathrm{A}$ \\
\hline $\mathrm{VL}$ & $-.34^{*}$ & $.54 \dagger$ & $-.35^{*}$ \\
$\mathrm{~V}$ & & $-.55 \dagger$ & .17 \\
$\mathrm{AL}$ & & & $-.67 \dagger$ \\
\hline
\end{tabular}

Note-VL = vocalization latency, $\mathrm{V}=$ number of vocalizations, $\mathrm{AL}=$ activity latency, $\mathrm{A}=$ activity level.

${ }^{*} p<.01 \quad+p<.001$

and 110.7 , respectively. This main effect of drug condition was significant $[F(2,54)=5.76, p<.005]$. The subsequent Newman-Kuels comparisons revealed that the anticholinergic groups differed from the control group $(p<.01)$, but did not differ from each other. The strain $x$ drug interaction was not significant.

Table 2 presents the intercorrelations among the four dependent variables. There was a significant positive correlation between vocalization latency and activity latency. All the other variables showed significant negative correlations, except for the comparison between number of vocalizations and activity level. This correlation was not significant.

\section{DISCUSSION}

Strain differences in vocalization and activity latencies were observed, with the Production Red chicks displaying significantly shorter latencies than the White Leghorns. The Production Reds also vocalized significantly more than the White Leghorns. Given the observation that White Leghorn chicks are more susceptible to TI and display longer durations of immobility than Production Reds (Hennig et al., in press), the present results are consistent with the suggestion that Whites are more emotional or perhaps more fearful of predation than Reds (Gallup et al., 1976).

Significant effects of anticholinergic drugs on vocalization latency, activity latency, and activity level were also observed. Both drugs reduced latencies and raised activity levels relative to water controls. These drugs also increased vocalization, although the effect was not significant. The effects of the two anticholinergic drugs did not differ significantly, but atropine was slightly more effective on the White Leghoms than scopolamine was, while the reverse was true for the Production Reds. Hennig et al. (in press) consistently found scopolamine to be more effective than atropine in reducing the duration of immobility, regardless of which strain was used. Given the observation that anticholinergics reduce TI duration and sometimes decrease susceptibility to TI, the present results are consistent with the interpretation that these anticholinergic drugs reduce emotionality. However, these effects seem to vary somewhat depending on factors such as the strain of the chicken and the handling experience of the subject. Another possible cause for these differences might be the suggested compromise between the tendencies to reinstate social contact and the attempts to avoid predation that Gallup and Suarez (1980) have proposed for open-field behaviors. However, this interpretation would be difficult to test directly.

The intercorrelations among the various dependent measures suggest that chicks have a tendency to reduce vocalization when inactive, but vocalize when active. This seems quite logical. To remain quiet and to freeze may have a survival value in a novel environment where there is a threat of predation. However, once the threat of predation is reduced, one might expect increased vocalization and movement in an attempt to locate conspecifics. The negative correlation between activity level and activity latency also makes sense, since the animals that become active sooner are also more active overall. Thus, the present results seem to agree with the view of open-field behavior proposed by Gallup and Suarez (1980).

\section{REFERENCES}

ArCher, J. (1973). Tests for emotionality in rats and mice: A review. Animal Behaviour, 21, 205-235.

CARLton, P. L. (1969). Brain acetylcholine and inhibition. In J. T. Tapp (Ed.), Reinforcement and behavior (pp. 288-327). New York: Academic Press.

DALY, H. B. (1968). Disruptive effects of scopolamine on fear conditioning and on instrumental escape learning. Journal of Comparative \& Physiological Psychology, 66, 579-583.

GALlUP, G. G., JR. (1977). Tonic immobility: The role of fear and predation. The Psychological Record, 27, 41-61.

Gallup, G. G., JR., Ledbetter, D. H., MASER, J. D. (1976). Strain differences among chickens in tonic immobility: Evidence for an emotionality component. Journal of Comparative \& Physiological Psychology, 90, 1075-1081.

Gallup, G. G., JR., SuArez, S. D. (1980). An ethological analysis of open-field behaviour in chickens. Animal Behaviour, 28, 368-378.

Hennig, C. W., Fazio, J. K., Hughes, C. A., Castaldi, W. R., * SPENCER, B. D. (1984). Duration of tonic immobility in chickens as a function of alpha-adrenergic receptor stimulation and blockade. Pharmacology, Biochemistry \& Behavior, 20, 731-738.

Hennig, C. W., McIntyre, J. F., Moriarty, D. D., Jr., Picerno, J. M., ALLEN, J. L. (in press). Differential cholinergic influences on the immobility response in various strains of domestic fowl. Pharmacology, Biochemistry \& Behavior, 30.

Hennig, C. W., Steinhoff, W. C., Booth, J. V. (1986). Central and peripheral effects of serotonin on the immobility response in chickens. Pharmacology, Biochemistry \& Behavior, 24, 1623-1627.

Hicks, L. E. (1976). Effects of anticholinergics on the habituation of tonic immobility in chickens. Behavioral Biology, 18, 199-209.

Hughes, R. A. (1982). Anticholinergic drugs, blood-brain-barrier and tonic immobility in chickens. Physiology \& Behavior, 29, 67-71.

KsIR, C. (1978). Scopolamine does not reduce tonic immobility in chickens. Physiological Psychology, 6, 521-523.

KsIR, C. (1979). Reply to Richard W. Thompson's "Comments on Ksir, C. 'Scopolamine does not reduce tonic immobility in chickens'." Physiological Psychology, 7, 456-457.

Maser, J. D., Gallup, G. G., JR., Hicks, L. E. (1975). Tonic immobility: Possible involvement of monoamines. Journal of Comparative \& Physiological Psychology, 89, 319-328.

NASH, R. F. (1978). Habituation and tonic immobility in chickens: Strain comparisons. The Psychological Record, 28, 109-114.

Plotnik, R., Mollenauer, S., \& SNyder, F. (1974). Fear reduction in the rat following central cholinergic blockade. Journal of Comparative \& Physiological Psychology, 86, 1074-1082.

RATNER, S. C. (1967). Comparative aspects of hypnosis. In J. E. Gordon (Ed.), Handbook of clinical and experimental hypnosis (pp. 550587). New York: Macmillan.

SuArez, S. D., \& GAlluP, G. G., JR. (1980). An ethological analysis of open-field behaviour in ducks Anas platyrhynchos. Bird Behaviour, 2, 93-105.

SunRez, S. D., \& GAlluP, G. G., JR. (1981a). An ethological analysis of open-field behavior in rats and mice. Learning \& Motivation, 12, 342-363.

Suarez, S. D., \& Gallup, G. G., JR. (1981b). Predatory overtones of open-field testing in chickens. Animal Learning \& Behavior, 9, 153-163.

SuArez, S. D., \& GAllup, G. G., JR. (1982). Open-field behavior in guinea pigs: Developmental and adaptive considerations. Behavioural Processes, 7, 267-274.

Thompson, R. W. (1979). Comments on Ksir, C. "Scopolamine does not reduce tonic immobility in chickens." Physiological Psychology, 7, 454-455.

Thompson, R. W., Piroch, J., Fallen, D., \& Hatton, D. (1974). 
A central cholinergic inhibitory system as a basis for tonic immobility (animal hypnosis) in chickens. Journal of Comparative \& Physiological Psychology, 87, 507-512.

Wallnau, L. B., Bordash, G. D., \& Corso, P., JR. (1981a). The effects of tryptophan and manipulations of serotonergic receptors on tonic immobility in chickens. Pharmacology, Biochemistry \& Behavior, 14, 463-468.

Wallnau, L. B., Bordash, G. D., \& Corso, P., JR. (1981b). Tonic immobility in domestic fowl: Possible interaction of serotonergic and dopaminergic mechanisms. Pharmacology, Biochemistry \& Behavior, 14, 469-473.
Wallnau, L. B., \& Gallup, G. G., JR. (1977). A serotonergic, midbrain-raphe model of tonic immobility. Biobehavioral Reviews, 1, 35-43.

Walsh, R. N., Cummins, R. A. (1976). The open-field test: A critical review. Psychological Bulletin, 83, 482-504.

Woodruff, M. L., Hatton, D. C., Frankl, M. B., \&eyer, M. E. (1976). Effects of scopolamine and physostigmine on tonic immobility in ducks and guinea pigs. Physiological Psychology, 4, 198-200.

(Manuscript received April 16, 1988.) 